\title{
CSAK AZÉRT, MERT MÁS SZÍNÜ A TOLLAM? - ÓVODAPEDAGÓGUSOK DRÁMAKÉPZÉSEN
}

\section{Novák Géza Máté}

Eötvös Loránd Tudományegyetem, Bárczi Gusztáv Gyógypedagógiai Kar

Ha elfogadjuk, hogy a drámán, színházon keresztül megvalósuló tanulás aktív és kreativ folyamat, azt is látjuk, hogy ez a megközelítés egyszerre mennyire problémacentrikus is. Akár az ismeretelsajátítás, akár az új jelentésteremtés tekintetében ez a pedagógiai eljárás megfelel a kreativitásfejlesztés kritériumainak. A dráma ebből az aspektusból nem korosztály-specifikus: óvodáskorú és felnőtt résztvevőinknél a tanulási folyamatnak egyaránt fontos eleme az alkotó-felfedező attitüd a foglalkozásokon, produktivitás az egyéni és csoportmunkában, a művészi eszközök rendhagyó alkalmazása a kihívást jelentő, szociális, etikai problémák körbejárása során (Novák, 2009a).

A drámának a tanulásban betöltött szerepének és erejének az érzékeltetésére az alábbi, idősíkokra koncentráló definíciót szeretném itt bevezetni ${ }^{1}$. Az alkalmazott (osztálytermi) dráma olyan, személyes és társadalmi szinten megfogalmazott problémáinkra érzékeny, kooperáción alapuló tanulási folyamat, amely az optimális tanulói választásoknak és döntéseknek jövőbe vetett és a változás irányába ható, a valós játékidőben képzeletbeli (mintha) világot fölépítő, cselekvéseken keresztül megformált itt és most elökészítése.

Valahol középütt játszva: ez egy lehetséges metafora lehet a számunkra, amikor a drámának és a színháznak a nevelésben betöltött szerepét próbáljuk meg körülírni. A játék során képesek vagyunk megrajzolni egy átmeneti teret itt és most, amelyben a szabadság érzetét nyújtjuk. Ebben a világban - átmenetileg szabadon formálhatjuk megértésünk új szintjeit (Somers, 2003).

Hogyan segíthetünk a színházi nevelési programokkal, hogyan alkothatunk esztétikai jelentéseket és új tanulási lehetőségeket a halmozottan hátrányos szociális helyzetü, a speciális nevelési igényü, vagy akár a szenvedélybeteg fiatalok számára? (Novák - Takács, 2009)

Optimális esetben nehéz különbséget tenni a tanárok müvészete és a müvészek tanítása között. „A tanár/művész szerep a rugalmasságot, a leleményességet, a személyes kreativitást, és a lehetőségek megragadására való képességet igényli, bárhol is tünjön föl”" ( $O^{\prime} N e i l l, 1995,83$. o.). A gyerekek és fiatalok drámamunkája során, miközben tapasztalataikat egy jelenetbe sürítik, alkotásuk értékelhető egy tisztán esztétikai szinten is. Müvészekkel és

\footnotetext{
${ }^{1}$ Lásd még ehhez - Gabnai Katalin, Szauder Erik, Kaposi László magyar nyelvű szakirodalomban alapvető körülírásait most nem érintve - a Trencsényi László által szerkesztett $A$ drámapedagógia, mint tudomány. Dr. Áma c. kötetünk definíciós kísérleteit. Engedtessék meg egy lábjegyzet erejéig polémiánkat kissé hosszabban idézni: „Mégiscsak arról van szó: a szinházi élmény eszközrendszere a fejlesztés/katarzis-elvü esztétikai élményekkel - ez a drámapedagógia legátfogóbb definiciója. (Fontosnak tartom jelezni - vitára szólítva hogy Novák Géza Máté az esztétikai élmény szerepét vállalja, de a katarzis-elv érvényesülését nem! Az arisztotelészi katarzis-elv tagadásából kiinduló Brecht, Grotowski és Brook szinházesztétikájának hatása a drámapedagógiában szerinte meghatározó.) Ám (a drámapedagógia) specifikuma mégiscsak az, hogy nem a nézöben végbemenö folyamatokra koncentrál, hanem elsősorban és meghatározóan a játszó személyben, játszó csoportban végbemenö folyamatokra, fejlödésre. Ha tehát a drámapedagógia világába bebocsátkozó aktorok nyilvánvalóan és nem csupán metaforikusan nevelök és növendékek, akkor a bennük végbemenó történések leirására a neveléstudomány avatott (ideértve a fontos társtudományt, a pedagógiai szociálpszichológiát). Ám mert az eszközrendszer minden elemében a színház, a szinjáték eszközrendszere, ezért a drámapedagógia tudományos diszciplinaként a szinháztudománynak is része. E két szülö gyermeke tehát. De felnött. Jussa van, hogy önmagához mérjék" (Trencsényi, 2008, 10. o.).
} 
pedagógusokkal készített interjúk sora árulkodik a közös jegyekről, John Somers kutatásában sorra veszi a két szerep közötti hasonlóságokat és különbözőségeket (Somers, 2003), ezekből gyüjtöttem néhányat az alábbi táblázatba:

\begin{tabular}{|l|l||}
\hline \multicolumn{1}{|c|}{ A TANÁR SZEREPE } & \multicolumn{1}{c|}{ A MÜVÉSz SZEREPE } \\
\hline $\begin{array}{l}\text { Részletes/különleges tárgyi tudást } \\
\text { birtokol. }\end{array}$ & $\begin{array}{l}\text { Vállalkozik a „személyes igazság” } \\
\text { keresésére egy választott médiumon } \\
\text { keresztül, keresve a bepillantás és } \\
\text { elmélyülés lehetőségét. }\end{array}$ \\
\hline $\begin{array}{l}\text { Megtervezi, értelmezi és a tanulók } \\
\text { elé tárja a szükséges tanulási } \\
\text { kontextusokat. }\end{array}$ & $\begin{array}{l}\text { Elkötelezi magát olyan munkák } \\
\text { mellett, amelyek kihívásokat } \\
\text { támasztanak önmaga számára. }\end{array}$ \\
\hline $\begin{array}{l}\text { Tudást és tanulási tapasztalatot ad át. } \\
\text { Törekszik egyensúlyt tartani az élet } \\
\text { szükségletei és az alkotás } \\
\text { sérthetetlensége között. }\end{array}$ \\
\hline $\begin{array}{l}\text { Inspirálja, támogatja, bátorítja és } \\
\text { meghallgatja a tanítványokat. }\end{array}$ & $\begin{array}{l}\text { Képes azonnal kommunikálni a } \\
\text { világgal esztétikai produktumait. }\end{array}$ \\
\hline $\begin{array}{l}\text { Értékeket közvetít a tanulók } \\
\text { munkájában. }\end{array}$ & Jelentős müalkotásokat produkál. \\
\hline $\begin{array}{l}\text { Megtalálja a bensővé tett érdeklődést } \\
\text { a közös munkában. }\end{array}$ & $\begin{array}{l}\text { Képes értékelö kritikával } \\
\text { viszonyulni saját munkájához. }\end{array}$ \\
\hline $\begin{array}{l}\text { Gondoskodik a tanulás friss, aktuális } \\
\text { szociális vetületeiröl. }\end{array}$ & $\begin{array}{l}\text { Nyitott és figyelmes a közönség } \\
\text { által adott reakciókra és az újabb } \\
\text { lehetőségekre. }\end{array}$ \\
\hline $\begin{array}{l}\text { Visszajelez a tanítás-tanulás } \\
\text { folyamatáról olyan módon, hogy a } \\
\text { résztvevőkben a jövöbeli tanulást is } \\
\text { motiválja. }\end{array}$ & $\begin{array}{l}\text { Képes hatásosan dolgozni olyan } \\
\text { szociális müvészeti területeken, } \\
\text { mint amilyen a dráma és a színház. }\end{array}$ \\
\hline $\begin{array}{l}\text { Képes fölfogni, hogy tanításának a } \\
\text { gesztusa nem szükségszerüen } \\
\text { eredményez a tanulókban tanulási } \\
\text { folyamatot (!). }\end{array}$ & $\begin{array}{l}\text { Képes önelemzően egyensúlyozni } \\
\text { az adásban és a befogadásban. }\end{array}$ \\
\hline $\begin{array}{l}\text { Folyamatosan frissíti tudását és } \\
\text { képességeit. }\end{array}$ & $\begin{array}{l}\text { Önkritikus marad saját } \\
\text { teljesítményeit illetően. }\end{array}$ \\
\hline
\end{tabular}

1. táblázat. A tanár és a müvész szerepe

\section{Drámapedagógiai eszközök alkalmazása az óvodás és kisiskolás korú tanulók múvészeti nevelésében}

A 21. Színház a Nevelésért Egyesület 2009 óta játssza „Csak azért, mert más színű a tollam?” - drámafoglalkozás az óvodában ${ }^{2}$ címü programját.

A foglalkozás témája a másság, különbözőség elfogadása és a küzdeni tudás pozitív értékeinek a megerösítése. A gyerekeket a közös alkotás élményén át, játékos színházi formákon keresztül vezetjük egy klasszikus mese, a Rút kiskacsa történetén keresztül. Az óvodai müvészeti nevelés keretei között olyan célokat kívánunk megvalósítani, mint a konfliktusok oldásának játékos tanítása, a kirekesztő viselkedés prevenciója.

${ }^{2}$ Az óvodásoknak szóló foglalkozást Novák Géza Máté és Bakos Gergely tervezték. 
Drámapedagógiai továbbképzésünk célja, hogy az óvodai és iskolai nevelés területén tevékenykedő pedagógusokat megismertesse a munkájukat hatékonyabbá tevő drámapedagógiai eszköztár alkalmazásának lehetőségeivel, annak alapvető pedagógiai eszközrendszerével. A továbbképzés középpontjába a képesség-központú és cselekvésen keresztül megvalósuló, az óvodás és kisiskolás korú gyermekek élményszintü bevonására építő pedagógiai folyamatot helyeztük.

A képzés elsődlegesen olyan tanulási-tanítási módszertanon alapul, amelyen keresztül a dramatikus sajátélmény átélhetővé, feldolgozhatóvá és végül az óvodai-iskolai környezetben adaptálhatóvá válik a résztvevő pedagógusok számára (Novák, 2009b).

$\mathrm{Az}$ óvodapedagógusoknak szóló képzés ${ }^{3}$ itt bemutatásra kerülő, egyik erősen fókuszált tananyaga a komplex drámafoglalkozás-tervezet készítésének a demonstrálása. A képzés fontos célja a dramatikus eljárások, a drámajáték-vezetés módszertanának megismertetése a müvészeti nevelés metodikai rendszerében való gondolkodás elsajátításával, valamint a pedagógusok szemléletváltásának az elősegítése. A sajátélményü kéttanáros foglalkozás-demonstráción a Rút kiskacsa címü meséből bontunk ki drámát a pedagógus résztvevőkkel. Az itt közölt képzési anyag elsősorban óvodapedagógusok számára szervezett drámapedagógus továbbképzésben hasznosítható azzal a céllal, hogy a 6-8 éves korosztállyal való drámamunkára nyújtson adaptációs lehetőségeket. Az alábbi foglalkozás-vázlat a téma, a célok és a tevékenységek, munkaformák ismertetésén túl olyan szakmai anyagokkal is kiegészül, mint a résztvevők által írt narratívák, illetve a reflexióskör dokumentációja.

Témák:

a) A másság, különbözőség, intolerancia, kirekesztés, befogadás.

b) Küzdeni tudás, kilépés az áldozat szerepéböl.

c) A pedagógus, mint segítő személy.

d) A tanuló személyiségének integritása; a szenvedésokozás tilalma.

Célok:

a) A tanítási dráma fiktív keretén belül döntéshelyzetek előidézése.

b) A különbözőségből, az elfogadás hiányából adódó problémahelyzet elemzése.

c) Konstruktív megoldások kidolgozása az adott (pedagógiai) konfliktushelyzetben.

d) A tanítási dráma munkaformáinak alkalmazási lehetőségeinek megismerése és elsajátítása közvetlen tapasztalatszerzés során.

e) A jelenségek kollektív értelmezésének müködése a drámában.

f) Segítsük az elfogadás attitüdjét, könnyítsük meg a beilleszkedést, fejlesszük a csoportkohéziót!

Résztvevők:

- Pedagógusok, óvodapedagógusok, illetve pedagógus-, gyógypedagógusjelöltek.

\footnotetext{
${ }^{3}$ Drámapedagógiai eszközök alkalmazása az óvodás és kisiskolás korú tanulók müvészeti nevelésében című pedagógus-továbbképzés. A képző drámatanárok: Novák Géza Máté és Varga Katalin, Soter-Line Oktatási Központ, Budapest, 2012.
} 
Időkeret:

- 135 perc (megbeszéléssel együtt)

Eszközök:

- Vizuális tábla, CD-lejátszó (+ klasszikus zene CD, pl. egy Vivaldi-concerto), Orbán Ottó versének fénymásolata (a résztvevők számára kiosztva), nagyméretü színes kendők, csomagoló papírok, íróeszközök, színes papírok és fillctollak.

Instrukciók, tevékenységek, munkaformák:

1. Klasszikus meséből indított drámaóra: idézzük fel körmesével a Rút kiskacsa történetét!

2. Lehetséges opció: a Hiányzó mesehősök címü játék elöre kiosztott kártyái közül az egyik a választott mese

3. Nagycsoportos egyeztetés: a négy legizgalmasabb pillanat címe/témája (Születés kacsák között, Kiüzetés a baromfiudvarból, Kacsamagány, Hattyúboldogság)

A drámafoglalkozás keretének felvételekor (a központi tanítási területet is meghatározó ún. kontextusépitó szakaszban) alapelv, hogy a játszók nem kaphatnak a vizsgált probléma és a közösen továbbépített történet szempontjából dekontextualizált feladatsorokat (Bolton, 1984). Viszont a kapott feladatok mindegyike erőteljes és világosan értelmezett szituációhoz kapcsolódik. Ilyen értelemben a dráma megtervezettsége, jól strukturáltsága nem manipuláció a tanár részéröl, sokkal inkább a tanulási folyamatot elörevivő, a mélyebb megértést segítő metodika. Innen nézve a drámatanár leginkább facilitálja, új felfedezésekre ösztönzi tanítványait, a közös tapasztalatok továbbépítése, és az új tudáskonstrukciók kibontakoztatása érdekében. A dráma célja legegyszerübben a boltoni rendszer értelmezése alapján így írható le: „a kölcsönös megértés fejlesztése az alapvető szellemi erőforrások mozgósításán keresztül” (Bolton, 1984. 151. o.). A kiscsoportos munkaformák (pl. tabló, tablórendezés, kiscsoportos improvizáció, jelenet) során a társas kreativitás is magas színvonalon valósulhat meg.

4. Lehetséges opció a dráma kontextusára: rajzfilmes keretet ajánlunk meg (rajzfilmkészítők: forgatókönyvírók, dramaturgok, rajzolók, szinkronszínészek, rendezők és producerek leszünk).

5. Tablók megalkotása (kiscsoportos munka a drámatanárok segítsége nélkül).

6. Tablórendezés (Oktatási cél itt különösen: A drámatanári kérdések és a tanulói válaszok kezelése.).

7. Gondolatkihangosítás (például Mit gondolnak a baromfiudvar lakói? Mi lehet most a Kacsamama fejében? Mit gondol most a Rút kiskacsa?).

8. Újabb tablórendezés a megértés mélyítése érdekében, a tabló bemozdítása (rögzített improvizáció némajátékkal, majd szinkronhanggal).

9. Az kontextust építő szakasz egész csoportos fejtése: mi a némajátékos jelenet üzenete? Hogyan készíthetők újabb változatok, hogyan folytatódhat ez a jelenet? Milyen jelentések felé mozdulhat el a csoport drámamunkája a mélyítő szakaszban? Milyen (a drámát építő) munkaformák alkalmazhatók annak érdekében, hogy ezek a jelentések a csoport számára általánosabb érvénnyel kiterjeszthetőek legyenek, akár egy még újabb (analógiás) gondolkodás irányába vezetve át a tréning résztvevőit?

10. Narratívák megalkotása kiscsoportban (napló, levélrészlet, riport). 


\section{Például:}

Képzeld, mekkora csalódás ért... Még a tojásban voltam, és hallottam kivülröl a vidám hápogást, úgyhogy összeszedtem minden eröm és bátorságom, és kitörtem a tojásból. Boldogan kiáltottam, hogy „,Mama!”, mire döbbent csend lett. Mindenki a mamához húzódott és nagyon furán néztek rám. Én is próbáltam hozzáférközni, de a többiek nem engedték. Nem értem, miért viselkednek így velem. Azóta senki sem játszik velem, a mama se figyel rám. Nagyon szomorú és magányos vagyok. Azért irok neked, hátha te megértesz. Üdvözlettel: a „Rút Kiskacsa” (a többiek hivnak igy).

(6. nap) Ma megint egyedül ébredtem. Amikor kinéztem a nádasból, láttam, hogy a testvérkéim vidáman játszanak a vízben nélkülem. Még a mamának se hiányzom. Nem értem, hogy miért nem szeretnek? Mi a baj velem? Csak azért, mert más színü a tollam? Bárcsak én is olyan szép sárga lehetnék, mint ők. Akkor biztos nem csúfolnának. Olyan egyedül érzem magam...

Kedves naplóm! Ma megint megpróbáltam játszani a testvéreimmel, de nem engedtek be maguk közé. Biztosan bennem van a hiba. Miért nem szeretnek? Pedig én úgy igyekszem. Nem is tudom, mit csinálhatnék még... Kedves testvéreim, azt kívánom nektek, hogy éljetek boldogan!

Most már tudom, hogy minden élőlény egyenértékü, de nem egyenrangú. Hosszú évek tapasztalata kellett hozzá, hogy megtanuljam. Mikor megszülettem, a világot egyszerünek és színesnek láttam. Utoljára születtem, gyengécske voltam, de örültem az életnek...

Kedves Családom! Úgy döntöttem, hogy világgá megyek, mert úgy érzem, nektek jobb lesz nélkülem. Sajnálom, hogy nem illek közétek - pedig én mindent megpróbáltam. Nem tudom, merre induljak, de talán megtalálom a helyem a világban. Mindig emlékezni fogok rátok...

2009. december 24. Karácsony. Kedves Naplóm! Már csak te maradtál nekem. Ülök a vízen, nézem a csupasz fákat és érzem a tollaim hegyén az égető jégkristályokat. Érzem, ahogy a fagy szétterjed a testemben. Már nem küzdök ellene... Már írni se tudok, úszóhártyáim közé fagyott a tollam...

...Kedves Naplóm, el sem hiszem, mi történt velem. Mintha álmodnék... Odamentem hozzájuk, azokhoz a csodálatos vízi madarakhoz. Mindenki - még a kacsák is - csodálattal és ámulattal nézett rám. Nem is értem, mintha nem is én volnék. Mindig arra vágytam, hogy befogadjanak és most végre megtaláltam az igazi társaimat! ${ }^{4}$

11. Egyperces jelenetek készítése kiscsoportos jelenetből kiindulva. Oktatási cél itt különösen: A személyes bevonódás, az érzelembe segítés megteremtése. Milyen formák alkalmazásával segítheti elő a drámatanár a jelenetek magasabb esztétikai és gondolati szinten való bemutatását? Például: A) tablóból mozduljon be a jelenet és tablóba érkezzen meg! B) törekedjenek a csoportok a sürítés eszközével a történet egy részletének felnagyítására! Legyen a bemutatás esztétikailag is igényes!

12. A központi pillanat felnagyítása: tanári szerepbelépés.

13. Tanári szerepbelépésből irányított kiscsoportos improvizáció (Miként illeszthetők be a tanulói alternatívák, új ötletek a jelenetek kidolgozásában?).

14. Koreográfia készítése zenei aláfestéssel.

15. Verstanulás (Orbán Ottó: Hess, hattyú, lengeteg...).

\footnotetext{
${ }^{4}$ A narratívákat az ELTE BGGYK BA-s hallgatói alkották meg a Dráma a nevelésben címủ kurzuson, a foglalkozások tesztelése során.
} 
16. Montázs készítése egész csoportban.

A foglalkozás során a játszók által létrehozott képek bemutatása egész csoportban, zenei átkötéssel, a szövegek (lásd a korábban megírt szövegek megszólaltatásával).

Például:

a) A drámatanár a Rút kiskacsa szerepébe lép és érveket gyüjt a baromfiudvar lakóitól. Mi a baj velem, azon túl, hogy más színü a tollam? Miért nem játszotok velem? Miért játszik most mással az, aki eddig a barátom volt? Ha a tóra megyünk fürdeni, miért nincs soha párom?

b) A Gazda megtalálja a Rút kiskacsát a tó jegébe fagyva. Hazaviszi, mert megsajnálja. Otthon a Gazdasszonnyal vitatkozni kényszerül: befogadjáke? A drámatanár (Ördög ügyvédje munkaforma) a Gazdasszony szerepébe lép, a csoporttól azt kéri, hogy vegyék föl a Gazda szerepét és gyüjtsenek érveket a kiskacsa befogadása mellett!

A dráma teret ad arra, hogy a benne részt vevők egyszerre élhessenek át „csoportélményt” és ezen keresztül önreflexiót. A képzésen résztvevőknek önállóan, páros és kiscsoportos munkaformákban, majd egész csoportos egyeztetések során fel kell tárniuk és meg kell ismerniük a dráma egyes elemeit. A megszokott tanulói/hallgatói részvételhez képest jóval aktívabb szerepvállalással, kreatív módon kell alkalmazniuk korábbi tapasztalataikat és be kell építeniük újonnan szerzett ismereteiket. A képzésen résztvevő óvodapedagógusok a sajátélmény feldolgozásához nélkülözhetetlen drámatanári visszajelzések és a reflexiós körben elhangzottak segítségével bővíthetik ismereteiket a dramatikus eljárások alkalmazásáról.

Az alábbi szöveg a sajátélményen alapuló foglalkozást követő beszélgetés egy részlete. A reflexiós szakaszban itt a tanári szerepbelépés alkalmazási lehetőségei jelennek meg a foglalkozást vezető drámatanár tolmácsolásában. Tanári szerep: a drámatanár által megjelenített karakter, segítségével a résztvevők cselekvése a történet kibontakoztatása érdekében facilitálható. A foglalkozás egészcsoportos improvizációjában és más dramatikus szakaszaiban a játszók a történet központi problémájába ilyen módon lesznek leginkább bevonhatók.

Tanár: Az volt az érdekes abban, amit mondtál, hogy te pedagógus fejjel gondoltad végig azt, hogy játszóként mennyire rossz volt kiközösitönek lenni. De vajon nekünk, tanároknak, mi a központi gondolatunk arról, amikor tanári szerepbe lépünk. Én elöször egy tanári szerepbe lépést ajánlottam Katának, drámában ez ugyanolyan szerep, akár az összes többi, viszont van tanulói szerepbe lépés és van tanári. A tanulói szerepbe lépésnél megajánlottam a kacsatestvérek és a kacsa- mama szerepét. Tanári szerepként, mert Kata az én trénerpáromként van itt köztetek, így milyen szerepek kerültek elö? Tehát milyen szerepet ajánlottam meg a trénerpáromnak?

Óvodapedagógus résztvevő: $A$ rút kiskacsát.

Másik résztvevő: A legkellemetlenebb...

Tanár: A legkellemetlenebb, a kitaszitott, a kiközösitett, egyszóval a legalacsonyabb státuszú szerepet. Ezt a szerepet a drámának ezen a pontján rátolni a gyerekekre tilos! Ha úgy tetszik, az én fejemben az van, hogy a kiszolgáltatottság a probléma, a kiközösités mechanizmusa és abban egy kiszolgáltatott szereplö, ez van a fókuszomban, ez a központi motivum, ami köré szervezem a drámát, ezt a szerepet nem tolhatom át a gyerekekre. Ha ketten 
vezetjük az órát, az egy nagyon jó helyzet, mert ha visszagondoltok a tavas jelenetre én gátlástalanul belevittem egy olyan szereplöt, megint tanári szerepböl, aki egy provokátor, a leggonoszabb kiskacsatestvér szerepét vettem fel, pontosan azért, hogy a ti bevonódásotokat mélyítsem, másrészt, hogy nektek legyen ez egy tapasztalásotok arról, hogy hoppá, mi is lehetnénk ilyenek. Igazából ilyenek vagyunk, mert mi is kacsák vagyunk. De ez a fökacsa, ez ki is mondja, amit mi itt némán gondolunk, hogy nem kellene beengedni a tóba. Nem tudom, hogy értiteke? Viszont ezt a két szerepet nem viheti el más, csak a két tanár. Aztán már jöhet feloldás, de meg kell mutatni ezt a részét, fel kell tárni ezeket a problémákat ahhoz, mert különben nem lesz belöle dráma. A drámának a kerete az maga a szerep is lehet, ami meghatározza, hogy van a kiközösitett és a kiközösitö, és van a provokátor és van az, aki mindezt elszenvedi. Van egy hatalmi játszma is, egy státuszbéli különbségekböl adódó játszma, ezt próbáljuk feltárni, ezt elemezzük. Megpróbáltam négy képbe sürittetni veletek az egészet, ezeknek a képeknek akár címet is adhattunk volna, de nem ez volt itt a leglényegesebb, hogy akkor az elsöt nevezzük el születésnek, a másodikat fürdésnek vagy kiközösitésnek, a harmadikat, amikor belefagy a vízbe, és a negyediket, amikor megtalálja az övéit. Hanem inkább maga a kiszolgáltatottságnak a megélése, és aztán, hogy mit is kezdünk ezzel, tehát ha valakit ilyen helyzetben látunk, és ennek a szituációnak magunk is elöidézöi vagyunk, vagy lehetünk. Aztán a fókusz átkerült oda, hogy mit tudunk játszani a segítségnyújtásról. Elindult onnan az improvizáció, ez már egy nagycsoportos improvizáció volt, amelynek a kereteit határoztuk meg, az inditó pillanatát. Ezt elég pontosan meg is rendeztétek, én kicsit kivülröl koreográfusként néha beleszóltam, hogy még ne susogjon a nádas, ne jöjjenek a jégtáblák, várjátok meg a zenét. Megvolt az elsö perc ebböl, ott van befagyva a hattyú szerepében Kata, a többiek tudják a maguk szerepét, és felhívtam rá a figyelmet, hogy egy ponton túl, mivel ez nem rögzitett improvizáció, hanem egy elöre megkoreografált jelenetböl elinditott, egészcsoportos improvizáció. Felhívtam a figyelmeteket, hogy szerepváltás következik majd be, de nem állitottam be a játékot, hanem azt mondtam, hogy kezdjük el játszani, és biztam abban, hogy a fantáziátok be fog indulni, és fölépititek azoknak a szerepét, akikre majd a megváltozott helyzetben szükség lesz. Elindult a jelenet, megtörtént minden, amit tudtunk, hogy eleve meg fog történni és aztán jött a csoport improvizációja, hogy hogyan mentjük meg. Nem határoztuk meg elöre azt, hogy hogyan nyújtunk segitséget a jégbe szorult hattyúnak és hogyan fogjuk öt megmenteni. Ez az az a pillanat, amikor már nem a kiközösités, hanem pont annak a feloldása, annak az ellentétje indul el a játszókban, arról fognak valamit tanulni a cselekvésen keresztül, hogy hogy megy végbe a segités, és a segitségnyújtás. Ez egészen addig folytatódott, amíg ott ültünk a kandalló elött a kiskacsával, és volt egy pillanat, amikor megnyugodtunk. Oké, megmentettük, és ezt a pillanatot úgy használtam ki, hogy megint azt mondtam, hogy hú, gyerekek, köszönöm szépen, álljunk meg. Nem azt mondtam, elemezzük a jelenetet, hanem: mi történt? Jött egy idöugrás. Kinéztünk az ablakon és azt láttuk, hogy itt a tavasz. Eltelt negyedév, öt másodperc alatt, és nem állt meg az improvizáció.

Résztvevő: Időben egy nagy ugrás volt.

Tanár: Onnantól kezdve már megint nálatok pattogott a labda, ti oldottátok meg a mese végét. Én csak adtam hozzá egy hangulati elemet, egy zenét. Kata nagyon ügyesen, ezzel a kendővel, nem tudom ki kötötte a nyakába, de valaki a nyakába kötötte ezt a sálat, és onnantól kezdve hattyú volt. Ez volt az átváltozás gesztusa. Innentöl kezdve megoldottátok a helyzetet, és már nem a segitségnyújtásról volt 
szó, hanem valamiféle szeretetteljes elköszönés volt itt a végén. Senki nem mondta az elején, hogy ezek a hattyúk táncolnak, aztán mégis táncoltak, ugye?

Résztvevő: Borzasztó tudatos volt, de azért sodort magával az esemény. Biztos voltam benne, hogy nem véletlenül vagy abban a szerepben, amiben vagy. De abban a helyzetben ezen nem gondolkoztam, nem érdekelt: játszottuk a szerepeket, ami tök jó volt. De ahogy most itt ülök, úgy gondolom, hogy nyilván tudatosan mondtál és csináltál mindent. De én ott abban a helyzetben nem éreztem azt, hogy neked meg kell felelnem, mert te elvársz tölem valamit.

Másik résztvevő: Ahogy a gyerekek sem érzik. Nekem a szerepváltás nagyon tetszett, hogy mindenki tudta, milyen szerepbe fog lépni. ${ }^{5}$

A képzés néhány jellemzőjét felvillantva jelen írásomban arra tettem kísérletet, hogy bemutassam a drámapedagógia eszköztárának, közelebbről az alkalmazott dráma munkaformáinak jellemzőit, lehetséges hatását a pedagógusképzés folyamatában. Ez egy művészetpedagógiai program felnőtt résztvevőkre adaptált tanfolyami müködéséről szólt. A köznevelés, az iskola világa jogosan várja el a müvészetpedagógiai projektektöl, hogy fejlesztéseik oktatási környezetben, a tanulás és a gyermeknevelés színterein is hatékonyak és sikeresek legyenek. Reméljük, hogy a 21. századi pedagógusképzés területén a hazai drámapedagógiai gyakorlat által kifejlesztett kreatív módszertani eljárások adaptációi egyre tudatosabb szakmai dokumentációkban jelennek majd meg.

\section{Irodalom}

Bolton, Gavin (1984): Drama as Education - An Argument for Placing Drama in the Centre of the Curriculum. Longman, Harlow.

Novák Géza Máté és Takács Gábor (2009): „Valahol középen müvészet és nevelés között.” A magyarországi színházi nevelés gyakorlata, helyzete, lehetőségei. Pedagógusképzés, 2009/1. sz. 163-167.

Novák Géza Máté (2009a): A zümmögés leküzdése. Egy drámapedagógiai akciókutatás első tanulságai. Iskolakultúra, 2009/9. sz. melléklete 3-19.

Novák Géza Máté (2009b): Inkluzív nevelés - Drámapedagógiai eszközök alkalmazása a sajátos nevelési igényű tanulók integrációjában. In: (uő., szerk.) pedagógus továbbképzés hallgatói szöveggyüjteményének megújított változata. Educatio Társadalmi Szolgáltató Nonprofit Kft., Budapest. 3-95.

O’Connor, P., Szauder E. és Bentsen E. (2003): Partnership, Protection and Participation: Principles for working in Drama with People with Special Needs. In: Heikkinen, H. (ed): Special Interest Fields of Drama, Theatre and Education. Jyväskylä University Press, Jyväskylä, 54-65.

O’Neill, C. (1995): Drama Worlds; A framework for process drama. New Hampshire: Heinemann.

\footnotetext{
${ }^{5}$ Drámapedagógiai eszközök alkalmazása az óvodás és kisiskolás korú tanulók müvészeti nevelésében címü pedagógustovábbképzés. A képző drámatanárok: Novák Géza Máté és Varga Katalin, Soter-Line Oktatási Központ, Budapest, 2012.
} 
Somers, J. (2003): Betwixt and Between Pedagogy and Art in the Initial Education of Teachers of Drama. In: Heikkinen, H. (ed): Special Interest Fields of Drama, Theatre and Education. Jyväskylä University Press, Jyväskylä. 18-32.

Trencsényi László (2008, szerk.): Dr. Áma. A drámapedagógia mint tudomány. Tananyagfejlesztés az Eötvös Loránd Tudományegyetem Neveléstudományi Doktori Iskolájában. Új Helikon Bt., Budapest. 